\title{
Histopathological Investigation of the Effect of Ozonated Water on Skin Ulcer Healing Process in Isolation Stress Mouse Model
}

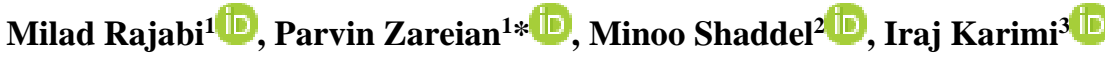

1. Dept. of Physiology, School of Medicine, AJA University of Medical Sciences, Tehran, Iran

2. Dept. of Parasitology and Mycology, School of Medicine, AJA University of Medical Sciences, Tehran, Iran

3. Dept. of Pathology, Faculty of Veterinary, Shahrekord University, Shahrekord, Iran

\begin{tabular}{|c|c|}
\hline Article Info & ABSTRACT \\
\hline doi $10.30699 / j a m b s .27 .125 .16$ & \multirow{2}{*}{$\begin{array}{l}\text { Background \& Objective: Skin ulcers and their slow healing are considered as one } \\
\text { of the important medical aspects. Nowadays, various antibiotics and materials are } \\
\text { used to accelerate the wound healing process. One of the methods taken in the field } \\
\text { of wound healing is using ozone. On the other hand, one of the factors that hurt the } \\
\text { speed of wound healing is stress. Therefore, the present study aimed to assess the } \\
\text { effect of ozonated water on healing of skin ulcers in stressful conditions. }\end{array}$} \\
\hline $\begin{array}{l}\text { Received: 2019/06/25; } \\
\text { Accepted: 2019/08/05; } \\
\text { Published Online: } 12 \text { Sep 2019; }\end{array}$ & \\
\hline \multirow[t]{2}{*}{$\begin{array}{l}\text { Use your device to scan and read the } \\
\text { article online }\end{array}$} & $\begin{array}{l}\text { Materials \& Methods: A total of } 80 \text { male mice were randomly divided into four } \\
\text { groups: stress -no ozone, stress - ozone, no stress-no ozone, no stress- ozone group. } \\
\text { Isolation stress was used (daily, } 4 \text { hours, for } 14 \text { days). The healing process was } \\
\text { evaluated based on measuring the wound surface area in days } 2,6,10 \text {, and } 14 \text { and } \\
\text { histopathological data. }\end{array}$ \\
\hline & $\begin{array}{l}\text { Results: Isolation stress by decreasing the fibroblast maturation and angiogenesis in } \\
\text { the wound leads to a reduction in the speed of wound healing. Ozone enhanced the rate } \\
\text { of tissue repair in both stress and stressless situations by decreasing inflammation and } \\
\text { increasing the fibroblast maturation, amount of collagen tissue, rate of re- }\end{array}$ \\
\hline \multirow[t]{2}{*}{$\begin{array}{l}\text { Corresponding Information: } \\
\text { Parvin Zareian, Dept. of Physiology, } \\
\text { School of Medicine, AJA University of } \\
\text { Medical Sciences, Tehran, Iran } \\
\text { E-Mail: zareianj2011@yahoo.com }\end{array}$} & $\begin{array}{l}\text { Conclusion: The results of this study implied that treatment with ozone could } \\
\text { accelerate the wound healing process and decrease the harmful effects of stress } \\
\text { conditions in healing process of animal model. }\end{array}$ \\
\hline & Keywords: Isolation stress, Ozonated water, Wound healing \\
\hline 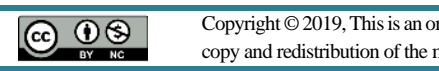 & $\begin{array}{l}\text { cess article distributed under the terms of the Creative Commons Attribu } \\
\text { noncommercial usages with proper citation. }\end{array}$ \\
\hline
\end{tabular}

\section{Introduction}

The process of wound healing and reducing its duration has attracted the attention of researchers for many years. Wound healing is divided into four steps: hemostasis, inflammation, proliferation, and remodeling. Briefly speaking, the hemostasis step includes the coagulation of blood platelets and clot formation. The inflammation step includes an influx of macrophages and neutrophils to the wound bed and phagocytosis. In the proliferation step, granulation tissue formation, matrix deposition, angiogenesis, and re-epithelialization occur. Finally, in the remodeling step, synthesis and collagen degradation, collagen deformation from type III to type II, increased tensile strength and wound contraction occur (1). Several factors affect the different stages of wound healing, such as the local microenvironment, immune system, and external environment. Interleukins (ILs) are substances that influence the immune system and regulate the process of wound healing. A clinical cohort study showed that recombinant human IL-7
(rhIL-7) did not affect HaCaT cell growth rates, but it enhanced cell migration of keratinocytes (2). IL-10, an anti-inflammatory cytokine, exerts its anti-scarring effect by reducing inflammatory responses, improving fibroblast activity and differentiation and increase in endothelial progenitor cells(EPCs) (3). At wound sites, IL-2 is known to activate macrophages and natural killer (NK) cells, and to promote the proliferation of Band T-lymphocytes (4).

Also, cell adhesion molecules (CAMs), a subset of cell adhesion proteins located on the cell surface, play an important role in the wound healing process. These molecules help cells stick to each other and their surroundings. Integrins, selectins, cadherins, and proteoglycans are groups of CAMs. Integrins participate in vascular sprouting and fibroblast infiltration into the wound clot. Therefore, integrins are an integral part of granulation tissue formation (5). It has been shown that blockade of E-selectin and P- 
selectin leads to delay in wound healing in mice (6). Lack of these molecules, especially L-selectin, reduces the accumulation of leukocytes inside the wound (7).

Animal and human studies have shown that stress reduces the speed of wound healing and increases recovery time $(\mathbf{8 , 9})$. Stress induces neurogenic inflammation in dendritic cells in the mouse skin at maturity (10). Foot-shock stress decreases the killing ability of polymorph nuclear cells to kill bacteria (11).

One of the important concerns of health teams to heal the wounds, especially large and severe ones, is the infection and its consequences. Increasing infection at each stage not only threatens the patient's life, but also alters the timing and quality of treatment. Therefore, preventive methods such as washing the wound with disinfectant solutions (betadine or topical antibiotics) are usually adopted in this regard. However, using this material makes the wound healing process to be long and associated with pain, irritation, and severe rash. Furthermore, the appearance of the healed skin might not satisfy the patient efficiently. So, the patient has to adopt costly methods to remove or decrease the wound traces, which are usually ineffective. One of the methods taken for wound healing is using ozone $(12,13)$. Ozone gas is a natural molecule, made up of three oxygen atoms. It can be in both gaseous and liquid forms. Experimental and clinical studies support ozone as a therapeutic agent for the treatment of wounds (12-14). Ozone oil increases migration and fibroblast activity at post-injury (13). Ozone increases the number of collagen fibers and fibroblasts at the wound bed (15); meanwhile, it increases VEGF, TGF$\beta$, and PDGF levels in wound exudates (16). Furthermore, ozone has an antimicrobial activity, which is effective in inhibiting bacterial growth (17).

Given that some people are at risk of occupational stress due to their jobs (e.g., military personnel and health care staff), the question arises whether ozone in solution form can have a therapeutic effect on skin ulcers during stressful situations and accelerate the wound healing process. Since no study has been conducted to assess the effect of ozone on skin ulcers at stressful situations so far, the purpose of this study was to evaluate the effect of ozonated water on healing skin ulcers in stressful and stressless situations.

\section{Materials and Methods}

\section{Materials}

The materials used in this study were ether, $0.9 \%$ physiology serum, betadine scrub (brown), 70\% counterfeit alcohol, non-sterile tampon, sample collection containers, formalin (10\%), scalpel blade no. 12 , and the consumption materials for toluidine blue dye and immunohistochemistry.

The equipment and devices used in this study were Micro-surgery set, Moser machine, microtome
(GMBH, Germany), coloring equipment, optical microscopes, Image J software caliper, and OPURA ozonated water generator (Canadian Green Solutions Inc.).

\section{Animals}

A total of 80 male mice (weight range: $25-30 \mathrm{gr}$ ) were divided into four groups. The animals were kept in the animal house of the Faculty of Veterinary Medicine, Shahrekord University, Iran. The animals were kept and fed at $18-26^{\circ} \mathrm{C}, 60-70 \%$ humidity, $12 \%$ illumination, and 12 hours of darkness. Each group consisted of 20 mice, including mice under stress and not using ozonated water, mice under stress and using ozonated water, mice without stress and not using ozonated water, mice without stress and using ozonated water. Sawdust was used within the cages during the maintenance period to provide a suitable platform.

\section{Stress Paradigm}

The stress model used was isolation, in which the mice were kept alone in separate cages for 4 hours per day from the beginning until the end of the sampling period. The time of isolation stress in all days of the test period was from $12 \mathrm{PM}$ to $4 \mathrm{PM}$. In the control group, all the six mice were kept in a single cage.

Ozone was done by ozonated water, generated by OPURA device with $100 \mathrm{mg} / \mathrm{L}$ concentration. Applying this amount of water to the wound area required 15 seconds, and the wound was washed once a day.

\section{Wound Formation}

The animals in each group were completely anesthetized by inhalation of the ether in the closed chamber and after shaving the hair behind the neck region by Moser, a scar of $6 \mathrm{~mm}$ diameter was created in non-infectious conditions with a biopsy punch. For this purpose, a circle (diameter: $6 \mathrm{~mm}$ ) was initially drawn on the skin. Then, the skin was raised and cut with a biopsy punch. The wound depth included derma and hypoderm. The wounds were made near the head of the animal so that the animal would not be able to see them.

\section{Measurement of Wound Size}

The wound surface area at days 2, 6, 10, and 14 was marked by a transparent paper and calculated by the picture analysis method via Image J software. Finally, the recovery percentage was calculated using the following formula. Using the following formula, the reduction percent of wound surface area was calculated for each mouse, and the average value was estimated in different groups.

$$
\text { recovery percent }=\frac{\text { wound surface area in day } X}{\text { wound } \text { surface area in day } 1}
$$

Where $X$ is the day in which the wound surface area is measured. 


\section{Euthanizing the Animals}

The mice were killed by intraperitoneal injection of a high dose of thiopental sodium at the end of days 2, 6, 10, and 14. All experiments were performed following the ethical guidelines set by the "Ethical Committee of AJA University of Medical Sciences" (IR. AJAUMS.REC. 1396.109), which completely coincided with the "NIH Guide for the Care and Use of Laboratory Animals".

\section{Preparing Tissue Cross-sections and Histological Examination}

In each group, five mice were killed on days 2, 6, 10, and 14. To take samples from the skin, strips with 2-3 $\mathrm{cm}$ length and $0.5-1 \mathrm{~cm}$ width were taken from the $1 / 3$ mid-ulcer area by whole thickness. So, the strip included both the central and marginal sections of the wound, as well as the intact area close to the wound bed symmetrically. After fixing the samples in $10 \%$ formalin, $5 \mathrm{~mm}$ cross-sections were prepared and the samples were colored by the hematoxylin-eosin method. The wound healing process was evaluated and rated histopathologically based on the presence of inflammatory cells, formation of granulation tissue, orientation of connective strands, epithelium recovery rate, formation of new vessels, and the quantity and maturity of fibroblasts.

We used a modified scoring system proposed by Abramov et al. (18). In this scoring system, each parameter is evaluated separately and a score of 0-3 is given (Table 1). The area under the curve (AUC) of every single histological score during the trial period was obtained using the trapezoid method.

\section{Statistical Analysis}

All data were presented in the form of a mean value \pm standard deviation. SPSS 16 (SPSS Inc., Chicago, IL., USA), one-way ANOVA statistical test, and Toki post-test were used to investigate the presence of a significant difference among the groups. P-Value of less than 0.05 was considered significant.

Table 1. The wound-healing histological scoring system.

\begin{tabular}{|c|c|c|c|c|}
\hline \multicolumn{5}{|c|}{ Score } \\
\hline Variable & 0 & 1 & 2 & 3 \\
\hline Acute inflammation & None & Scant & Moderate & Abundant \\
\hline Chronic inflammation & None & Scant & Moderate & Abundant \\
\hline Granulation tissue & None & Scant & Moderate & Abundant \\
\hline fibroblast maturation & Immature & Mild maturation & Moderate maturation & Fully matured \\
\hline Collagen deposition & None & Scant & Moderate & Abundant \\
\hline Re-epithelialization & None & Partial & $\begin{array}{l}\text { Complete but immature or } \\
\text { thin }\end{array}$ & Complete and mature \\
\hline Neovascularization & None & $\begin{array}{c}\text { Up to five vessels per } \\
\text { HPF }\end{array}$ & $6-10$ vessels per HPF & $\begin{array}{c}\text { More than } 10 \text { vessels per } \\
\text { HPF }\end{array}$ \\
\hline
\end{tabular}

\section{Results}

Ozonated water enhances the coetaneous wound healing rate. The average wound size in different groups and on different days is shown in Table 2. As shown in this table, the wound surface area, except in the first group (stressed-no ozone group) decreases over time.

Stressed-no ozone group: mice under stress and not using ozonated water, stress-ozone group: mice under stress and using ozonated water, no stress-no ozone group: mice without stress and not using ozonated water, no stress- ozone group: mice without stress and using ozonated water.

Percentage reduction in the wound surface area in "stressed-no ozone", "stressed-ozone", "no stress-no ozone" and "no stress-ozone" groups was 1\%, 65\%, $50 \%$, and $85 \%$, respectively.

Comparison of the percentage reduction in the wound surface area in "stressed-no ozone" and "no stress-no ozone" groups showed that stress significantly reduced the wound healing rate $(P<0.0001)$. Also, ozone in both stressful and stressless groups caused a significant reduction in the wound surface. The effect of ozone on wound healing in the stressed group was greater than the non-stressed one (64\% versus $35 \%)$. 
Table 2. Average wound surface area $\left(\mathrm{mm}^{2}\right)$ on the sampling days in different groups

\begin{tabular}{ccccc} 
Groups & Day 2 & Day 6 & Day 10 & Day 16 \\
\hline Stress - no ozone & 0.41 & 0.42 & 0.43 & 0.40 \\
\hline Stress - ozone & 0.23 & 0.15 & 0.10 & 0.07 \\
\hline No stress- no ozone & 0.34 & 0.30 & 0.21 & 0.17 \\
\hline No stress - ozone & 0.22 & 0.13 & 0.03 & 0.03 \\
\hline
\end{tabular}

\section{Evaluation of Re-epithelialization in the Wound}

Wound re-epithelialization data on different days and in different groups were shown in Figure 1A. As the figure shows, over time, the level of wound reepithelialization increased.

Comparing the AUC of re-epithelialization in "stressed-no ozone" and "stressed-no ozone" groups showed that stress did not have a significant effect on the re-epithelialization level (Table 3). Ozone in the stressed group, as well as in the stressless group, significantly increased the rate of re-epithelialization $(P<0.0001)$. The maximum and minimum reepithelialization occurred in the "no stress-ozone" and "no stress-no ozone" groups, respectively (Table 3).

\section{Evaluation of New Vascularization in the Wound}

The extent of new vascularization in the wound in different groups during four sampling stages is reported in Figure 1B.

Comparing the AUC for new vascularization in "stressed-no ozone" and "no stress-no ozone" groups showed that stress caused a significant reduction of new vascularization in the wound $(P=0.03)$.

Ozone significantly increased angiogenesis in both stressed $(P<0.0001)$ and no stress groups $(P=0.02)$. The lowest and the highest levels of angiogenesis were in the "stressed-no ozone" and the "stressed-ozone" groups, respectively (Table 3 ).

\section{Evaluation of Collagen Level in the Wound}

The results of collagen formation in the wound area during four sampling days in experimental groups are shown in Figure 1C.

Comparing the AUC for wound collagen level in "stressed-no ozone" and "no stress-no ozone" groups showed that stress increases collagen formation in the wound area $(P=0.007)$. Also, ozone significantly increased wound collagen formation in both stressed $(P=0.002)$ and no stress groups $(P<0.0001)(\underline{\text { Table } 3})$.

\section{Evaluation of Fibroblast Maturation in the Wound}

Wound fibroblast maturation on sampling days in the experimental groups is shown in Figure 1D. Comparing the AUC for the fibroblast maturation in "stressed-no ozone" and "no stress-no ozone" groups showed that stress reduced fibroblast maturation in the wound area $(P=0.005)$.

Ozone significantly increased wound fibroblast maturation in both stressed $(P=0.005)$ and no stress groups $(P<0.0001)$. The maximum and minimum fibroblast maturation was in the "stressed-ozone" and the "stressed-no ozone" groups, respectively (Table 3).

\section{Evaluation of Granular Tissue Size in the Wound}

The data of granular tissue size in the wound area in different groups during sampling days are shown in Figure 1E. Comparing the AUC for the size of the granulation tissue in "stressed-no ozone" and "no stress-no ozone" groups showed that stress increased granulation tissue size in the wound area, but this increase was not significant $(P=0.3)$. Ozone significantly increased granulation tissue size in both stressed $(P=0.005)$ and no stress groups $(P<0.0001)$ (Table 3).

\section{Evaluating Inflammation Level in the Wound Area}

Figure 1F shows the mean values of the inflammation level in the wound area during the four stages of sampling. As shown in this figure, over time, the level of inflammation decreased in all groups.

Comparing the AUC for the inflammation level in "stressed-no ozone" and "no stress-no ozone" groups showed that stress has no significant effect on the level of inflammation $(P=1)$. In addition, ozone decreased inflammation levels in both stressed and no stress groups $(P<0.0001)$ (Table 3). 
Table 3. The comparison of AUCs for histopathological variables in different groups. Stress -no ozone group: mice under stress and not using ozonated water, stress-ozone group: mice under stress and using ozonated water, no stress-no ozone group: mice without stress and not using ozonated water, no stress- ozone group: mice without stress and using ozonated water.

\begin{tabular}{|c|c|c|c|c|c|}
\hline$\underbrace{\text { Group }}_{\text {Variable }}$ & $\begin{array}{l}\text { Stress- } \\
\text { no ozone }\end{array}$ & $\begin{array}{l}\text { Stress- } \\
\text { ozone }\end{array}$ & $\begin{array}{c}\text { No } \\
\text { stress- } \\
\text { no zone }\end{array}$ & $\begin{array}{l}\text { No stress- } \\
\text { ozone }\end{array}$ & P-value \\
\hline $\begin{array}{c}\mathrm{Re}- \\
\text { epithelialization }\end{array}$ & $16.4 \pm 1.3$ & $30 \pm 3.1$ & $15.2 \pm 2$ & $33.2 \pm 1$ & $\begin{array}{l}* P<0.0001 \text { compared to stress-no ozone group. } \\
\Psi P<0.0001 \text { compared to no -stress-no ozone } \\
\text { group. } \\
\# P<0.0001 \text { compared to stress - no ozone group. }\end{array}$ \\
\hline $\begin{array}{c}\text { New } \\
\text { vascularization }\end{array}$ & $11.6 \pm 1$ & $23.6 \pm 2.6$ & $16.4 \pm 1.5$ & $19.6 \pm 1.9$ & $\begin{array}{l}\# P<0.0001 \text { compared to stress }- \text { no ozone group. } \\
\Psi P=0.02 \text { compared to no stress-no ozone group. } \\
* P=0.03 \text { compared to stress- no ozone group. }\end{array}$ \\
\hline $\begin{array}{c}\text { Wound collagen } \\
\text { level }\end{array}$ & $23.2 \pm 1.2$ & $30 \pm 3$ & $\begin{array}{c}13.6 \pm \\
1.5\end{array}$ & $36 \pm 2.2$ & $\begin{array}{l}\# P=0.002 \text { compared to stress -no ozone group. } \\
\Psi P<0.0001 \text { compared to no stress-no ozone } \\
\text { group. } \\
* P=0.007 \text { compared to stress- no ozone group }\end{array}$ \\
\hline $\begin{array}{l}\text { Fibroblast } \\
\text { maturation }\end{array}$ & $19.2 \pm 1.2$ & $27.6 \pm 1.6$ & $\begin{array}{c}13.6 \pm \\
1.2\end{array}$ & $36 \pm 1$ & $\begin{array}{l}\# P<0.0001 \text { compared to stress -no ozone group. } \\
\Psi P<0.0001 \text { compared to no stress-no ozone } \\
\text { group. } \\
* P=0.005 \text { compared to stress- no ozone group. }\end{array}$ \\
\hline $\begin{array}{l}\text { Wound granular } \\
\text { tissue }\end{array}$ & $20.8 \pm 0.8$ & $32.8 \pm 2.2$ & $\begin{array}{c}22.4 \pm \\
1.6\end{array}$ & $34 \pm 1.1$ & $\begin{array}{l}\# P<0.0001 \text { compared to stress -no ozone group. } \\
\Psi P<0.0001 \text { compared to no stress-no ozone } \\
\text { group. }\end{array}$ \\
\hline $\begin{array}{c}\text { Inflammation } \\
\text { level }\end{array}$ & $24.4 \pm 1$ & $4.8 \pm 1.2$ & $\begin{array}{c}23.2 \pm \\
1.6\end{array}$ & $5.2 \pm 0.8$ & $\begin{array}{l}\# P<0.0001 \text { compared to stress -no ozone group. } \\
\Psi P<0.0001 \text { compared to no stress-no ozone } \\
\text { group. }\end{array}$ \\
\hline
\end{tabular}

\section{Discussion}

The results of our study showed that isolation stress by decreasing the fibroblast maturation and angiogenesis in the wound leads to a reduction in the speed of wound healing. SStress directly affects some components in the healing process by activating the hypothalamus-pituitary-adrenal axis and the sympathetic-adrenal-medullary axis. Activation of these two axes resulted (19). Healing rate correlates with serum corticosterone level (20).

Stress resulted in inhibition of fibroblast growth by the increase in serum level adrenalin, noradrenalin, and cortisol (21). Stress also decreases the effect of genes initiating the inflammatory phase in the wound and causes a delay in the wound healing process (22).

In this study, ozone enhanced the rate of tissue repair in both stressed and non-stressed groups by decreasing inflammation and increasing the fibroblast maturation, amount of collagen tissue, rate of re-epithelization, new vascularization, and granulation tissue size.
Our findings showed that ozone can promote wound healing by increasing expression of fibroblast genes such as collagen-I, $\alpha$-SMA, and TGF- $\beta 1$. Also, ozone can improve epithelial-mesenchymal transition process in the fibroblasts, which is important for the fibroblast activity (13).

The results of collagen strings implied that using ozone increases collagen strings in the wound healing area. In this regard, Kim HS et al. (2009) reported that using $0.1 \mathrm{~mL} /$ day of ozonated olive oil would increase collagen's synthesis and fibroblast proliferation at the wound bed in the guinea pig (15).

Fibroblasts have an important role in scar and new tissue formation. They promote the wound healing via secreting many factors, such as matrix metallopeptidase-14 (mmp-14), basic fibroblast growth factor (bFGF), and fibroblast growth factor-9 (FGF-9) (13). Fibroblasts secrete growth factors that contribute to angiogenesis in various cells and tissues (23-25). 
A

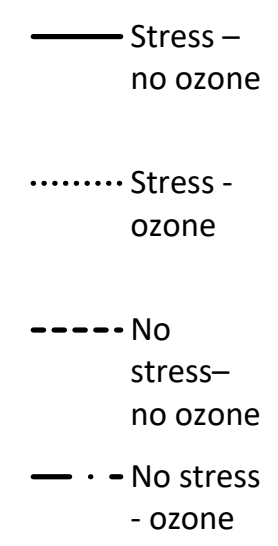

D
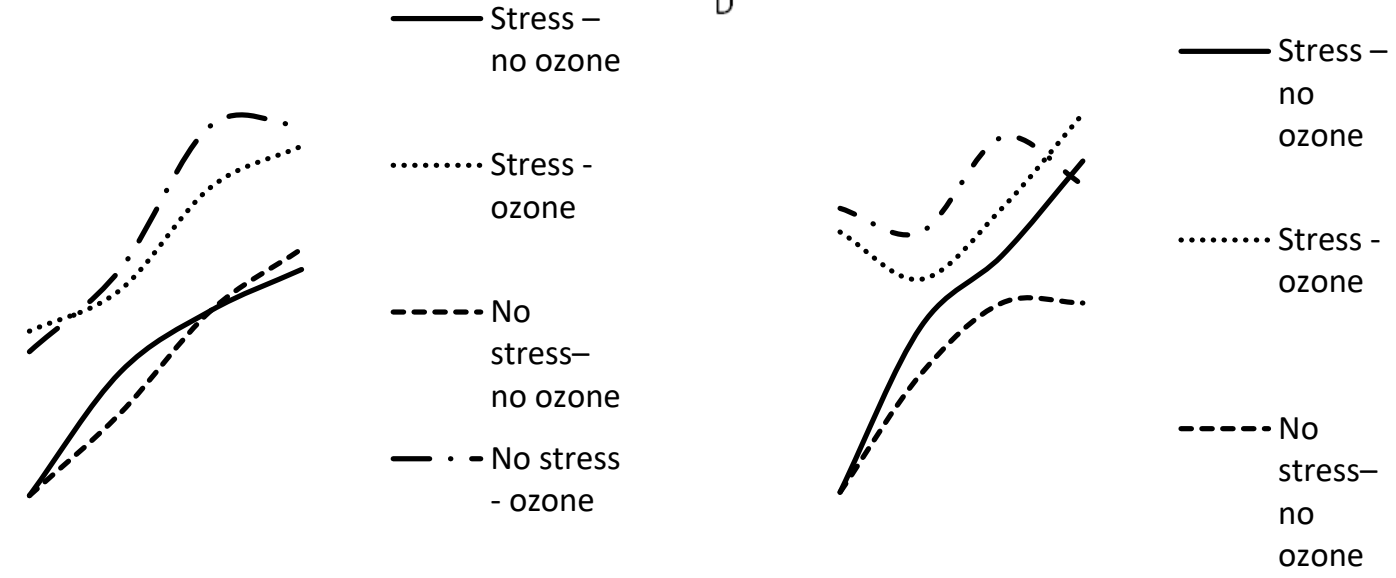

$E$

B
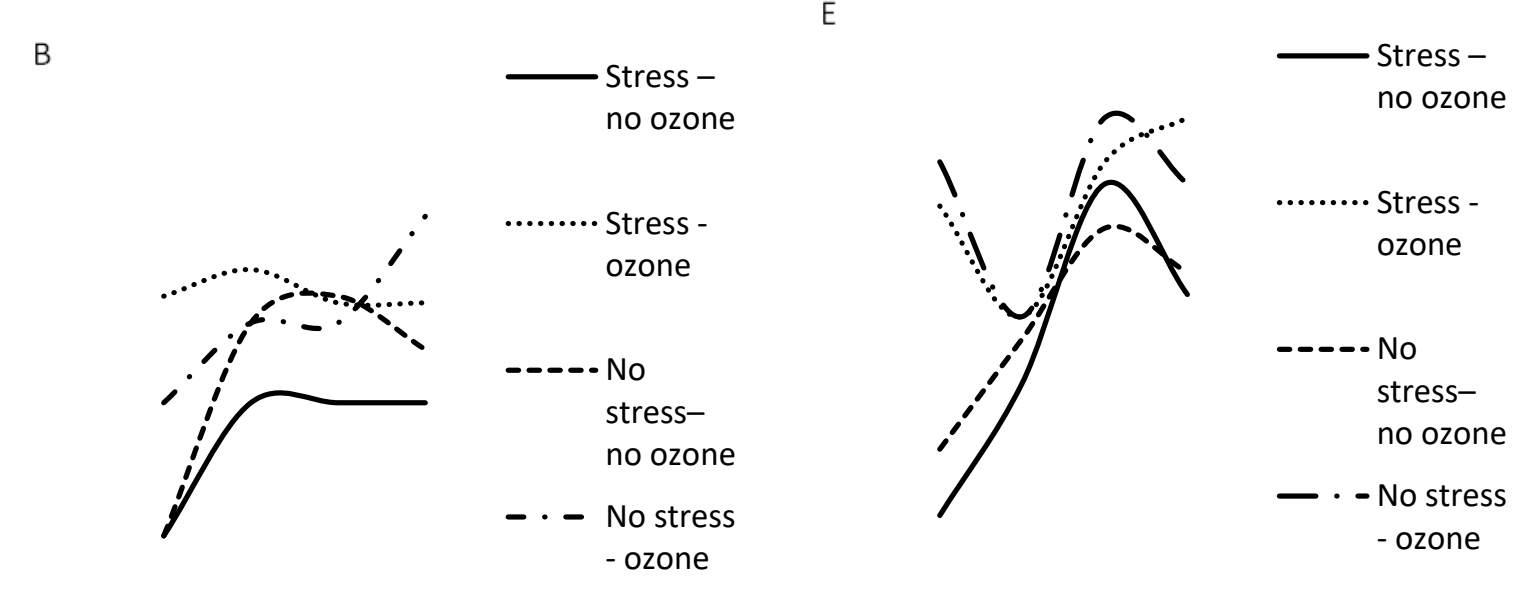

C

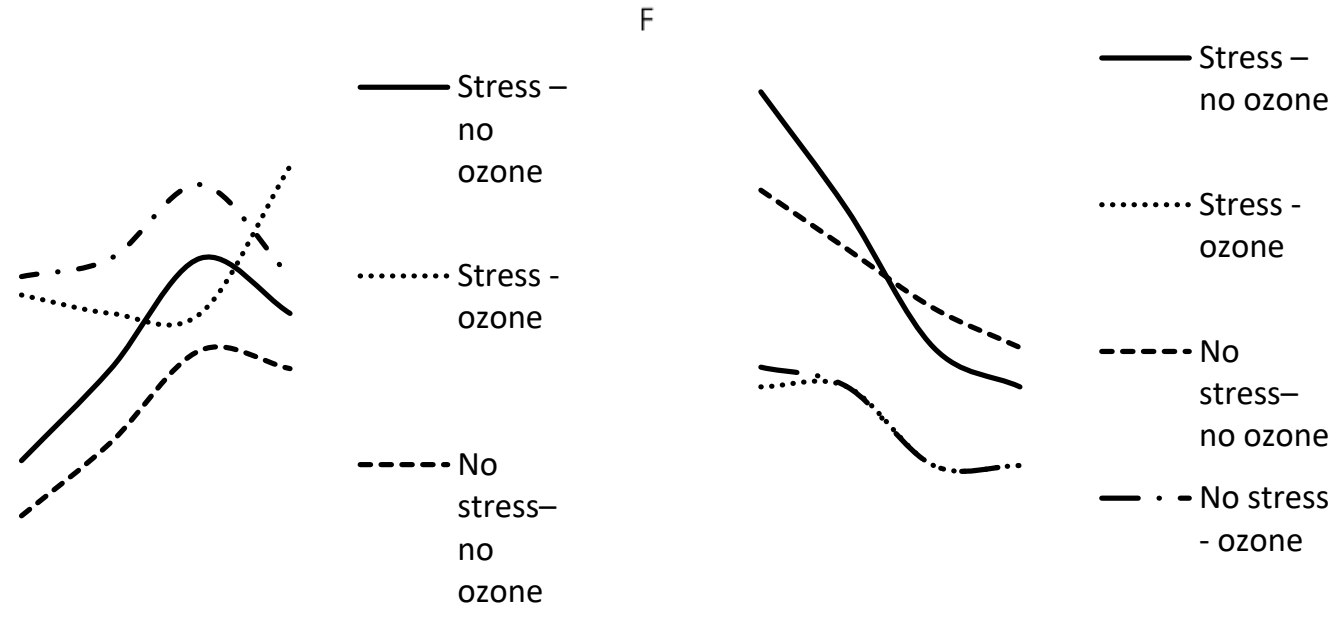

Figure 1. Wound re-epithelialization (A), new-vascularization (B), wound collagen level (C), fibroblast maturation (D), wound granular tissue size (E) and inflammation level (F) on the sampling days and in different groups (scoring 0-3) 
The results of inflammatory status in the treatment area implied that ozone significantly reduces inflammation. Moreover, ozone reduces inflammation by reducing levels of tumor necrosis factor- $\alpha$ and nuclear transcriptional factor-kappa $\mathrm{B}(\mathrm{NF \kappa B})$ and increasing activity of superoxide dismutase (26-28).

In this study, ozone therapy induced new vascularization in the wound area. Some previous studies reported that ozone promoted expression of the angiogenesis marker, VEGF (28). Ozonated serum enhances nitric oxide (NO) production by human endothelial cells and leads to vasodilation in ischemic areas (29).

It is stated that during stress the free radicals increase (30) and oxidative materials delay the wound healing $(31,32)$. Ozone reacts with several biological components and results in moderate oxidative stress. Moderate oxidative stress activates nuclear factorerythroid 2-related factor 2 (Nrf2). Activation of Nrf2 results in the production of numerous antioxidant enzymes, such as SOD, GPx, glutathione-s-transferase (GST), and catalase (CAT). Therefore, the therapeutic effect of ozone on wound healing may be through the activation of the antioxidant protection system in the body (27).

\section{Conclusion}

The results of this study showed that even though stressful situations delayed the process of wound healing, ozone can reduce the effect of stress and help to return to near-normal levels. Treatment by ozone accelerated wound healing in both stressed and nonstressed groups by decreasing inflammation and increasing the fibroblast maturation, amount of collagen tissue, rate of re-epithelialization, new vascularization, and granulation tissue size. Given the observed effect of ozone on accelerating the wound healing process in this study and also in the literature, conducting great clinical trials with proper design in this regard seems to be a critical step towards the treatment of chronic ulcers.

\section{Acknowledgments}

This study was funded by AJA University of Medical Sciences, Tehran, Iran. The authors are grateful to the Army Medical University Vice-Chancellor for Research.

\section{Conflict of Interest}

The authors had no conflicts of interest to disclose.

\section{References}

1. Enoch S, Leaper DJ. Basic science of wound healing. Surgery. 2005; 23(2):37-42. [DOI:10.1383/surg.23.2.37.60352]

2. Bartlett A, Sanders AJ, Ruge F, Harding KG, Jiang WG.Potential implications of interleukin-7 in chronic wound healing. Exp Ther Med. 2016;12(1):33-40. [DOI:10.3892/etm.2016.3263] [PMID] [PMCID]

3. King A, Balaji S, Le LD, Crombleholme TM, Keswani SG. Regenerative wound healing: The role of interleukin-10. Adv Wound Care (New Rochelle). 2014;3(4):315-23. [DOI:10.1089/wound.2013.0461] [PMID] [PMCID]

4. Broughton G, Janis JE, Attinger CE. The basic science of wound healing. Plast Reconstr Surg. 2006; $\quad 117(7 \quad$ Suppl): $12 S-34 S$. [DOI:10.1097/01.prs.0000225430.42531.c2] [PMID]

5. Koivisto L, Heino J, Häkkinen L, Larjava H.Integrins in wound healing. Adv Wound Care (New Rochelle). 2014; 3(12):762-83. [DOI:10.1089/wound.2013.0436] [PMID] [PMCID]

6. Yukami T, Hasegawa M, Matsushita Y, et al.Endothelial selectins regulate skin wound healing in cooperation with L-selectin and ICAM1.J Leukoc Biol. 2007; 82(3):519-31. [DOI:10.1189/jlb.0307152] [PMID]

7. Nagaoka T, Kaburagi Y, Hamaguchi Y. Delayed wound healing in the absence of intercellular adhesion molecule-1 or L-selectin expression. Am J Pathol. 2000;157(1):237-47. [DOI:10.1016/S0002-9440(10)64534-8]

8. Gouin JP, Kiecolt-Glaser JK. The impact of psychological stress on wound healing: methods and mechanisms. Crit Care Nurs Clin North Am. 2012; 24(2):201-13.

[DOI:10.1016/j.ccell.2012.03.006] [PMID] [PMCID]

9. Christian LM, Graham JE, Padgett DA, Glaser R, Kiecolt-Glaser JK. Stress and wound healing. Neuroimmunomodulation. 2006; 13(5-6): 337-46. [DOI:10.1159/000104862] [PMID] [PMCID]

10. Joachim RA, Handjiski B, Blois SM, Hagen E, Paus R, Arck PC. Stress-induced neurogenic inflammation in murine skin skews dendritic cells towards maturation and migration: key role of intercellular adhesion molecule-1/leukocyte function-associated antigen interactions. Am J Pathol. 2008; 173(5):1379-88. [DOI:10.2353/ajpath.2008.080105] [PMID] [PMCID] 
11. Shurin MR, Kusnecov A, Hamill E, Kaplan S, Rabin BS. Stress- induced alteration of polymorphonuclear leukocyte function in rats. Brain Behav Immun. 1994; 8(2):163-9. [DOI:10.1006/brbi.1994.1015] [PMID]

12. Fitzpatrick E, Holland OJ, Vanderlelie JJ. Ozone therapy for the treatment of chronic wounds: A systematic review. Int Wound J. 2018; 15(4):63344. [DOI:10.1111/iwj.12907] [PMID]

13. Xiao W, Tang H, Wu M, et al. Ozone oil promotes wound healing by increasing the migration of fibroblasts via PI3K/Akt/mTOR signaling pathway. Biosci Rep. 2017; 37(6): BSR20170658. [DOI:10.1042/BSR20170658] [PMID] [PMCID]

14. Degli Agosti I, Ginelli E, Mazzacane B, et al. Effectiveness of a short-term treatment of oxygenzone therapy into healing in posttraumatic wound. Case Rep Med. 2016; $2016: 9528572$. [DOI:10.1155/2016/9528572] [PMID] [PMCID]

15. Kim HS, Noh SU, Han YW, et al. Therapeutic effects of topical application of ozone on acute cutaneous wound healing. J Korean Med Sci. 2009; 24(3):368-74 https://doi.org/10.3346/jkms.2009.24.3.368 [DOI:10.3346/jkms.2000.15.3.368] [PMID] [PMCID]

16. Zhang J, Guan M, Xie C, Luo X, Zhang Q, Xue Y. Increased growth factors play a role in wound healing promoted by noninvasive oxygenozonetherapy in diabetic patients with foot ulcers. Oxid Med Cell Longev. 2014; 2014: 273475. [DOI:10.1155/2014/273475] [PMID] [PMCID]

17. Borges GÁ, Elias ST, da Silva SM, et al. In vitro evaluation of wound healing and antimicrobial potential of ozone therapy. J Craniomaxillofac Surg. 2017; 45(3):364-70. [DOI:10.1016/i.jcms.2017.01.005] [PMID]

18. Abramov Y, Golden B, Sullivan M, et al. Histologic characterization of vaginal vs. abdominal surgical wound healing in a rabbit model. Wound Repair Regen. 2007;15(1):80-6. [DOI:10.1111/j.1524-475X.2006.00188.x] [PMID]

19. Slominski AT, Zmijewski MA. Glucocorticoids inhibit wound healing: novel mechanism of action. J Invest Dermatol. 2017; 137(5):1012-14. [DOI:10.1016/j.jid.2017.01.024] [PMID] [PMCID]

20. Padgett DA, Marucha PT, Sheridan JF. Restraint stress slows cutaneous wound healing in mice. Brain Behav Immun. 1998; 12(1):64-73. [DOI:10.1006/brbi.1997.0512] [PMID]

21. Romana-Souza B, Otranto M, Almeida TF, Porto LC, Monte-Alto-Costa A. Stress-induced epinephrine levels compromise murine dermal fibroblast activity through $\beta$-adrenoceptors. Exp
Dermatol.

2011;20(5):413-9.

[DOI:10.1111/j.1600-0625.2010.01239.x]

[PMID]

22. Mercado AM, Padgett DA, Sheridan JF, Marucha PT. Altered kinetics of IL-1 $\alpha$, IL-1 $\beta$, and KGF-1 gene expression in early wounds of restrained mice. Brain Behav Immun. 2002. 16(2):150-62. [DOI:10.1006/brbi.2001.0623] [PMID]

23. Yun YR, Won JE, Jeon E, et al. Fibroblast growth factors: Biology, function, and application for tissue regeneration. J Tissue Eng. 2010; 2010: 218142. [DOI:10.4061/2010/218142] [PMID] [PMCID]

24. Newman AC, Nakatsu MN, Chou W, Gershon PD, Hughes CC. The requirement for fibroblasts in angiogenesis: fibroblast-derived matrix proteins are essential for endothelial cell lumen formation. Mol Biol Cell. 2011; 22(20): 3791-800. [DOI:10.1091/mbc.e11-05-0393] [PMID] [PMCID]

25. Presta M, Dell'Era P, Mitola S, Moroni E, Ronca R, Rusnati M. Fibroblast growth factor/fibroblast growth factor receptor system in angiogenesis. Cytokine Growth Factor Rev. 2005;16(2):159-178 [DOI:10.1016/j.cytogfr.2005.01.004] [PMID]

26. Azuma K, Mori $\mathrm{T}$, Kawamoto $\mathrm{K}$, et al. Antiinflammatory effects of ozonated water in an experimental mouse model. Biomed Rep. 2014; 2(5):671-74. [DOI:10.3892/br.2014.290] [PMID] [PMCID]

27. Sagai M, Bocci V. Mechanisms of action involved in ozone therapy: Is healing induced via a mild oxidative stress? Med Gas Res. 2011; 1:29. [DOI:10.1186/2045-9912-1-29] [PMID] [PMCID]

28. Biçer Ş, Sayar İ, Gürsul C, et al. Use of ozone to treat ileostomy dermatitis in an experimental rat model. Med Sci Monit. 2016; 22: 757-65. [DOI:10.12659/MSM.897696] [PMID] [PMCID]

29. Valacchi G, Bocci V. Studies on the biological effects of ozone: Release of factors from human endothelial cells. Mediators Inflamm. 2000; 9 (6):271-6. [DOI:10.1080/09629350020027573] [PMID] [PMCID]

30. Srivastava KK, Kumar R. Stress, oxidative injury and disease. Indian J Clin Biochem. 2015; 30(1): 3-10. [DOI:10.1007/s12291-014-0441-5] [PMID] [PMCID]

31. Wu H, Li F, Wang S, et al. Ceria nanocrystals decorated mesoporous silica nanoparticle based ROS-scavenging tissue adhesive for highly efficient regenerative wound healing. Biomaterials. 2018. 151: 66-77 [DOI:10.1016/j.biomaterials.2017.10.018] [PMID] 
32. Mittal M, Siddiqui MR, Tran K, Reddy SP, Malik AB. Reactive oxygen species in inflammation and 1126-67［DOI:10.1089/ars.2012.5149]［PMID] tissue injury. Antioxid Redox Signal. 2014;20 (7):

\section{How to Cite This Article:}

Rajabi M, Zareian P, Shaddel M, Karimi I. Histopathological Investigation of the Effect of Ozonated Water on Skin Ulcer Healing Process in Isolation Stress Mouse Model. J Adv Med Biomed Res. 2019; 27 (125) :16-24

\section{Download citation:}

BibTeX $|\underline{\text { RIS }}|$ EndNote $\mid$ Medlars $\mid$ ProCite $\mid$ Reference Manager $\mid$ RefWorks

\section{Send citation to:}

(9. 